\title{
The Development and Comprehensive Evaluation of Control System Training Kit as a Modular-Based Learning Media
}

\author{
Nurhening Yuniarti, Ahmad Luthfi Setiawan, Didik Hariyanto
}

Yogyakarta State University, Yogyakarta, Indonesia

\begin{abstract}
The aims of this study are 1) to develop the electromagnetic control system training kit that can be used as learning media on the basis of a modular design, and 2) to comprehensively evaluate the learning media through three different approaches, i.e., functional-based test, experts' judgment, and userbased assessment. The design and development process of the learning media utilized the widely known ADDIE model that comprises analysis, design, development, implementation, and evaluation. The finding showed that the learning media developed passed the functional-based test and worked well as designed. Moreover, the experts of media design and learning material quality judged the learning media as feasible to use in the learning process. The user also rated the learning media as feasible.
\end{abstract}

Keywords - comprehensive evaluation, control system training kit, modular-based, learning media

\section{Introduction}

The learning and teaching process is one positive example of communication activity in the field of education. As it often happened amongst a teacher and students, the communication between those parties is basically the act of transferring the information from one to another.

DOI: $10.18421 /$ TEM93-52

https://doi.org/10.18421/TEM93-52

Corresponding author: Didik Hariyanto, Department of Electrical Engineering Education, Faculty of Engineering, Yogyakarta State University, Indonesia.

Email: didik hr@uny.ac.id

Received: 14 June 2020.

Revised: 08 August 2020.

Accepted: 14 August 2020.

Published: 28 August 2020.

(c) BY-NC-ND (C) 2020 Nurhening Yuniarti, Ahmad Luthfi Setiawan \& Didik Hariyanto; published by UIKTEN. This work is licensed under the Creative Commons AttributionNonCommercial-NoDerivs 4.0 License.

The article is published with Open Access at www.temjournal.com
In the concept of teacher-centered learning, the teacher is the one who has the main authority to arrange the process of learning in the classroom [1]. Moreover, the teacher is the principal-agent to deliver the information and actively talks while the students passively listen and are receptive. This kind of learning is generally associated with the traditional approach. Since education is always changing to find its best equilibrium, recently the teacher-centered education has significantly shifted toward a studentcentered approach [2], [3]. This student-centered approach may lead the students to have an equal interaction with teachers. The students could actively participate in communication and discussion instead of exclusively listening to the teacher in the classroom [4].

To ensure the communication between the teacher and students may run smoothly, in principle, there are four essential components required in the communication process: sender, message, channel, and receiver [5]. The sender is one who provides the message to another, while the receiver is one who takes the advantages from that particular message. The message is the information that needs to be delivered, and the channel is the media used to transmit that information. In the vocational high school level in which student-centered learning is considered a suitable approach to escalate the learning achievement, the learning media is one essential tool to accommodate the knowledge transfer between both teacher and student. The learning media, particularly in the practical-based subject matter, is a tool that could significantly help the students to easily comprehend the theoretical thing [6].

According to [7], learning media is an educational tool that can be used as a channel in the learning activities to enhance the effectiveness and efficiency in achieving the learning objectives. From a broader perspective, learning media is not only talked as a tool but it also discussed methods and techniques used to make communication and interaction more effective between instructors and learners in the classroom learning process [8]. Besides, learning media has a broad scope, including humans, 
learning materials, or studies that build a special condition for students to conveniently obtain knowledge, skills, or attitudes [9]. In [7], it is stated that the use of learning media in the teaching and learning process could arouse new desires and interests, generate motivation and stimulation of learning activities, and bring positive psychological influences to students. Subsequently, the learning media can be classified into four, namely, 1) printedbased media, 2) audio-visual media, 3) computerbased media, and 4) combined printed- and computer-based media [10].

In [11] are suggested several factors to be considered for selecting the learning media, i.e., the instructional objectives to be achieved, student characteristics, the desired learning stimulus type (audio, visual, motion, etc.), learning environment, local condition, and the coverage area to be served. In [12] it is postulated that the use and selection of learning media should take into account: 1) the objectives to be achieved, 2) the compatibility of the media with the learning material, 3) the availability of supporting facilities and infrastructure, and 4) the student characteristics. In [13] is also mentioned that certainly, media educational goals can vary depending on the specific theme and objectives of a lesson, the age of the student, theoretical basic, etc. One can summarize that the development of media by following the above-mentioned considerations may gain several benefits in the process of learning and teaching communication between the knowledge provider and the recipient.

The findings on the preliminary observation at Cokroaminoto Pandak Vocational High School showed that the learning condition on the subject of installing and operating a control system was not in the ideal situation. It found that the main problem was the lack of learning media, particularly at the competency of operating an electromagnetic control system. Since the learning media is one crucial tool in conveying the knowledge in the learning process, this condition may lead the knowledge transfer between both sides (teacher and students) distracted. On one side, the teacher faced difficulties in explaining the learning material, and on the other side, the students struggled a lot to absorb the knowledge. This fact is the main reason to be resolved in this study. Accordingly, one of the main objectives of this current study is to develop the electromagnetic control system training kit that can be used as a learning media for enhancing the knowledge reception by learners. The intended learning media will be designed by implementing a modular-based approach. In the context of engineering, the modular design is an approach to subdivide a system into smaller parts (modules) that can be independently created and then used in different configurations to drive multiple functionalities [14]. The modular system is chosen due to some advantages, i.e., flexibility in reusability, ease in assembling, ease in fault localization, and economy [14], [15]. Another main objective of this study is to evaluate the learning media, whether it is feasible to use it in the learning process. The evaluation scheme will be conducted in three different approaches: 1) the evaluation related to the functional work of the modules, 2) the expert-based assessment concerning the media design and learning material aspects, and 3) the evaluation based on the perspective of the user.

\section{Research Method}

\subsection{Research Design}

The primary focus of this study is the development of the training kit of the electromagnetic control system that can be used as a learning media in the instructional system. One widely used method to design and develop the instructional system is Instructional System Design (ISD). In ISD, one of the commonly known models is ADDIE, which is the abbreviation from five sequences of a development process: Analysis, Design, Development, Implementation, and Evaluation [16]. Therefore, the current study uses the ADDIE model to develop the intended training kit. It is also important to emphasize that the learning media developed will be evaluated comprehensively through three different approaches: functional-based test, experts' judgment, and user-based assessment.

\subsection{Developing Instruments for Evaluation}

One important step to gather information from the respondent is through the questionnaire. The questionnaire is defined as a research instrument that typically consists of a set of questions. The process of developing the questionnaire should be started by taking into consideration the research purposes [17]. After that, work continues by identifying the aspects of assessment, including the indicators of each aspect by reviewing related literature. Regarding the evaluation of the training kit in terms of the media design in this study, the questionnaire is comprised of three aspects, i.e., design, technical, and usefulness. The design aspect has five indicators with ten questions. Meanwhile, the technical aspect has six indicators with 14 questions. The last aspect, the usefulness aspect, has four indicators with seven items of questions. The outline of the questionnaire can be seen in Table 1 . 
Table 1. The questionnaire outline of the media-based evaluation

\begin{tabular}{|c|c|c|c|}
\hline No & $\begin{array}{c}\text { Evaluation } \\
\text { Aspects }\end{array}$ & Indicators & $\begin{array}{c}\text { Items } \\
\text { Number }\end{array}$ \\
\hline \multirow[t]{5}{*}{1} & \multirow[t]{5}{*}{ Design } & Interface Design & 1,2 \\
\hline & & Component Layout & 3 \\
\hline & & Labeling & $4,5,6$ \\
\hline & & Applicative Function & $7,8,9$ \\
\hline & & Ergonomic & 10 \\
\hline \multirow[t]{6}{*}{2} & \multirow[t]{6}{*}{ Technical } & Reliability & 11,12 \\
\hline & & Operating Techniques & $13,14,15$ \\
\hline & & Easy to Use & $16,17,18$ \\
\hline & & $\begin{array}{l}\text { Conformity with School } \\
\text { Infrastructure }\end{array}$ & 19,20 \\
\hline & & Ease of Maintenance & 21,22 \\
\hline & & Safety & 23,24 \\
\hline \multirow[t]{4}{*}{3} & \multirow[t]{4}{*}{ Usefulness } & Facilitating the Teachers & 25,26 \\
\hline & & $\begin{array}{l}\text { Clarify the Learning } \\
\text { Material }\end{array}$ & 27,28 \\
\hline & & Shortening Learning Time & 29 \\
\hline & & $\begin{array}{l}\text { Attracting Students' } \\
\text { Attention }\end{array}$ & 30,31 \\
\hline
\end{tabular}

Concerning the learning material evaluation of the training kit, the questionnaire consists of two aspects, i.e., quality of learning material and usefulness. The aspect of the learning material quality has eight indicators with 16 questions. Meanwhile, the usefulness aspect has four indicators with nine items of questions. Table 2. shows the detailed outline of the intended questionnaire.

Table 2. The questionnaire outline of the learning material-based evaluation

\begin{tabular}{|c|c|c|c|}
\hline No & $\begin{array}{c}\text { Evaluation } \\
\text { Aspects }\end{array}$ & Indicators & $\begin{array}{c}\text { Items } \\
\text { Number }\end{array}$ \\
\hline \multirow[t]{8}{*}{1} & \multirow[t]{8}{*}{$\begin{array}{l}\text { Quality of } \\
\text { Learning } \\
\text { Material }\end{array}$} & $\begin{array}{l}\text { Compliance with } \\
\text { Competencies }\end{array}$ & 1,2 \\
\hline & & $\begin{array}{c}\text { Suitability of the Media } \\
\text { with the Material }\end{array}$ & 3 \\
\hline & & $\begin{array}{l}\text { Appropriateness within } \\
\text { Picture and Text }\end{array}$ & $4,5,6$ \\
\hline & & $\begin{array}{c}\text { Supporting the Delivery } \\
\text { of Material }\end{array}$ & 7,8 \\
\hline & & Adding Knowledge & 9,10 \\
\hline & & Material Structure & 11 \\
\hline & & $\begin{array}{l}\text { Conformity to the } \\
\text { Student Needs }\end{array}$ & $12,13,14$ \\
\hline & & Clarity of the Instructions & 15,16 \\
\hline \multirow[t]{4}{*}{2} & \multirow[t]{4}{*}{ Usefulness } & Facilitating the Teachers & 17,18 \\
\hline & & $\begin{array}{c}\text { Clarify the Learning } \\
\text { Material }\end{array}$ & $19,20,21$ \\
\hline & & $\begin{array}{c}\text { Shortening Learning } \\
\text { Time }\end{array}$ & 22,23 \\
\hline & & $\begin{array}{l}\text { Developing the Student } \\
\text { Interest }\end{array}$ & 24,25 \\
\hline
\end{tabular}

The two previous questionnaires have been created for collecting information from the experts' point of view. Meanwhile, the last questionnaire will be made to gather information from the students' perspectives.
A different strategy has been used to construct the questionnaire in which some items are changed into a negative wording format. The strategy to combine a positive and negative wording question is chosen in order to minimize the response and acquiescence bias that usually arise from the school-age respondents. As seen in Table 3., there are four aspects considered in the questionnaire, i.e., quality of the learning material, design, technical, and usefulness. The aspect of the learning material quality has six indicators with ten questions, whereas the design aspect has two indicators with four questions. The next aspect, the technical aspect, has six indicators with ten questions, and the last aspect, the usefulness, has two indicators with four items of question.

Table 3. The questionnaire outline of the student-based evaluation

\begin{tabular}{|c|c|c|c|}
\hline No & $\begin{array}{c}\text { Evaluation } \\
\text { Aspects }\end{array}$ & Indicators & $\begin{array}{c}\text { Items } \\
\text { Number }\end{array}$ \\
\hline \multirow[t]{6}{*}{1} & \multirow[t]{6}{*}{$\begin{array}{l}\text { Quality of } \\
\text { Learning } \\
\text { Material }\end{array}$} & $\begin{array}{c}\text { Supporting the Delivery } \\
\text { of Material }\end{array}$ & 1,2 \\
\hline & & $\begin{array}{c}\text { Suitability of the Media } \\
\text { with the Material }\end{array}$ & 3,4 \\
\hline & & Adding Knowledge & 5 \\
\hline & & Material Structure & 6 \\
\hline & & $\begin{array}{l}\text { Conformity to the Student } \\
\text { Needs }\end{array}$ & $7,8^{*}$ \\
\hline & & Clarity of the Instructions & 9,10 \\
\hline \multirow[t]{2}{*}{2} & \multirow[t]{2}{*}{ Design } & Component Layout & 11 \\
\hline & & Labeling & $12 *, 13,14$ \\
\hline \multirow[t]{6}{*}{3} & \multirow[t]{6}{*}{ Technical } & Reliability & 15 \\
\hline & & Operating Techniques & 16 \\
\hline & & Easy to Use & $17^{*}, 18,19$ \\
\hline & & $\begin{array}{l}\text { Conformity with School } \\
\text { Infrastructure }\end{array}$ & 20,21 \\
\hline & & Ease of Maintenance & 22 \\
\hline & & Safety & 23,24 \\
\hline \multirow[t]{2}{*}{4} & \multirow[t]{2}{*}{ Usefulness } & $\begin{array}{l}\text { Developing the Student } \\
\text { Interest }\end{array}$ & $25,26^{*}$ \\
\hline & & Shortening Learning Time & 27,28 \\
\hline
\end{tabular}

Note:

*: negative wording question

All three questionnaires mentioned above are constructed on a Likert scale. The respondents have an option to mark one out of four alternatives spanning from "strongly agree" to "strongly disagree" to express their thought.

\subsection{Validity and Reliability of the Instruments}

After the initial draft of instruments has been made, the work continued by ensuring whether the instruments meet the validity and reliability criteria. The validity test is the evaluation to see the degree to which the assessment tool could accurately measure what it is supposed to measure. Meanwhile, the reliability test is the evaluation to see the degree to 
which the assessment tool could consistently measure when it is used to measure repeatedly.

There are many types of validity tests. By considering certain aspects of time, simplicity, and accuracy, the validity test in this study has been conducted through a content validity. The content validity, many researchers called as a logical or rational validity, is the validity test that refers to the degree to which the questionnaire items on the assessment tools are relevant and representative enough to measure [18]. The content validity in this study was done through a rational analysis from two competent experts. The experts examined each item in the questionnaire whether it was relevant, needed revision, or was not relevant. The process continued by refining the items according to the experts' comments and recommendations. Just after the refinement, all items in the questionnaires were considered valid to be used to measure.

In the meantime, the reliability test in this study was done by applying two different approaches. Firstly, the reliability tests for both instruments of media-based and learning material-based were measured by applying a crude index agreement method [19]. This method examines the degree of agreement for each response of a set of questions that resulted from different evaluators. This kind of test is widely known as inter-rater agreement or inter-rater reliability. The results of the inter-rater reliability test showed that the reliability score for the media-based instrument was 0.71. Meanwhile, the learning material-based instrument scored 0.76 from the reliability test conducted. In general, researchers agreed that one instrument could be considered reliable when the reliability score reached 0.7 or above [20], [21]. Furthermore, Guilford (cited in [22]) offered the reliability coefficients classification to interpret the level of reliability as seen in Table 4. Based on that, those two reliability scores achieved are categorized in the acceptable criteria. Secondly, the reliability test for the instrument of user-based assessment was measured by using Cronbach's alpha. Analysis of the result indicated that the reliability of the instrument was very high (Cronbach's alpha was 0.905).

Table 4. Reliability coefficients interpretation

\begin{tabular}{|lll|l|}
\hline \multicolumn{2}{|c|}{ Reliability Coefficient $(\mathrm{r})$} & Interpretation \\
\hline 0.00 & $\leq \mathrm{r}<0.20$ & Very Low \\
\hline 0.20 & $\leq \mathrm{r}<0.40$ & Low \\
\hline 0.40 & $\leq \mathrm{r}<0.70$ & Moderate \\
\hline 0.70 & $\leq \mathrm{r}<0.90$ & High \\
\hline 0.90 & $\leq \mathrm{r} \leq \quad 1.00$ & Very High \\
\hline
\end{tabular}

\subsection{Participants}

It is important to note that there are three different aspects of evaluation. The first is the evaluation of the trainer kit in terms of the functional work of the modules. There was one experienced student of an undergraduate electrical engineering program responsible for this test. The second evaluation of the trainer kit is related to both media design and learning material aspects. Two media-based experts conducted the evaluation in terms of media design. The experts involved in this evaluation were chosen based on their expertise in media design competence. Moreover, another evaluation of the trainer kit was related to the learning material. Since the trainer kit was created to support the learning and teaching process in the subject of installing and operating a control system, thus the experts were selected based on their experiences and competence in that particular subject. The evaluation in this respect was conducted by two evaluators. Third, the evaluation of the trainer kit is based on the users' perspective. The users for this evaluation purpose were the XI grade students of the Electricity Utilization Installation Techniques Department of Cokroaminoto Pandak Vocational High School. There were 15 students involved in this evaluation.

\subsection{Evaluation Procedure}

The evaluation process in this study involved two different groups of respondents. The first group is the group of experts which is comprised of two groups. The first group of experts examines the training kit related to media design. Meanwhile, the second group of experts is responsible for evaluating the training kit on the aspect of the learning material. For this kind of respondents, the evaluation was conducted by first briefly explaining the purpose of the evaluation. Then, the researchers distributed the questionnaire in a paper-and-pencil format to the respective groups. At the same time, the evaluators could examine the training kit to make a precise judgment. After the completion, the questionnaires were collected back to the researchers.

The second respondent are the students who will be a target user for this training kit. First of all, a brief explanation of the research's purpose was given to the students. After that, the questionnaire was distributed to the students in a paper-and-pencil format. A different procedure was used in this evaluation by giving a chance to the students to use the training kit for a specific practical task. The students may express what they thought by marking out the Likert scale on the questionnaire. In the end, the researchers collected all the questionnaires. 


\subsection{Data Analysis}

Data analysis is a process to evaluate the collected data from the study by using analytical and statistical tools in order to discover the useful information needed. In this study, the data analysis used is a descriptive analysis. The descriptive analysis is one essential step to quantitatively describe the collection of raw data gathered from the study in a meaningful way. It is also important to note that the collected data from the respondents are in a Likert-scale form which is a widely used technique to scale responses. In connection with that, it needs a categorization to classify the respondents' responses. In this study, the categorization method is adopted from [23] and [24]. This method classifies the responses collected from the questionnaire based on the total score of Likertscale. As can be seen in Table 5., the criteria of the respondent's responses are divided into four different levels spanning from "very poor" into "very good".

Table 5. Classification of respondent's response

\begin{tabular}{|c|c|c|c|}
\hline \multicolumn{3}{|c|}{ Score Range } & Criteria \\
\hline $\mathrm{M}+1.5 \mathrm{SD}$ & $<\mathrm{X} \leq$ & $M+3 S D$ & Very Good \\
\hline $\mathrm{M}+0.5 \mathrm{SD}$ & $<\mathrm{X} \leq$ & $\mathrm{M}+1.5 \mathrm{SD}$ & Good \\
\hline $\mathrm{M}-0.5 \mathrm{SD}$ & $<\mathrm{X} \leq$ & $\mathrm{M}+0.5 \mathrm{SD}$ & Poor \\
\hline $\mathrm{M}-1.5 \mathrm{SD}$ & $<\mathrm{X} \leq$ & $\mathrm{M}-0.5 \mathrm{SD}$ & Very \\
\hline
\end{tabular}

where:

$\mathrm{X}=$ respondent response

$\mathrm{M}$ = ideal mean score

$=1 / 2 \times$ (ideal maximum score + ideal minimum score)

SD = ideal standard deviation

$=1 / 6 \mathrm{x}$ (ideal maximum score - ideal minimum score)

\section{Research Findings}

\subsection{The Development of Electromagnetic Control System Training Kit}

The development of the electromagnetic control system training kit starts with the analysis step. One suitable method to deal with the analysis step is through need assessment. In [25] are suggested six activities in conducting a need assessment; namely 1) determine the present condition, 2) define the job, 3) rank the goal in order of importance, 4) identify the discrepancies, 5) determine positive areas, and 6) set priorities for action. The need assessment in this study has been conducted by interviewing subject matter teachers who are involved in the teaching process. Moreover, classroom learning activity related to the practice of electromagnetic control systems is also observed. The result of this step will be used as basic information for the next steps.

The following step is design. This phase utilizes the output from the analysis phase to make a detailed plan or a blueprint for the next phase, the development phase. The design phase in this step comprises 1) identifying the components needed, 2) designing the electronic circuits for each module, and 3 ) designing the training kit as a united system.

The working is continued by developing the training kit based on the information collected from the analysis and design phases. Most of the work in this step focuses on the electronic aspects. There are 13 electronic modules constructed, i.e., 1) 1 Phase and 3 Phases Power Source Module, 2) Circuit Protection Module, 3) Thermal Overload Relay Module, 4) Time Delay Relay Modules, 5) Magnetic Contactor Modules, 6) Volt-Meter Selector Switch Module, 7) Push Button Switch Modules, 8) Jogging Switch Module, 9) Emergency Switch Module, 10) Auto-Manual Selector Switch Module, 11) Volt Meter Module, 12) Ampere Meter Modules, and 13) Current Transformer Module. The appearance of the training kit, including each module attached can be seen in Figure 1.

In general, the training kit could be used to support the practice of a motor control system in the subject of installation and operation of electromagnetic control systems. This training kit was designed to accommodate 1 phase and 3 phases of electrical source that are commonly used for driving the electric motor system. It should be noted that the training kit was constructed in a modular approach. This strategy may lead students to arrange the module flexibly according to a specific task. Accordingly, it is possible to connect one module to another by using a set of specific cables included. There are also instruments attached in the training kit that can be used to monitor the current and voltage of the circuit. A module to anticipate a failure connection or an abnormal current is also available in this training kit. 


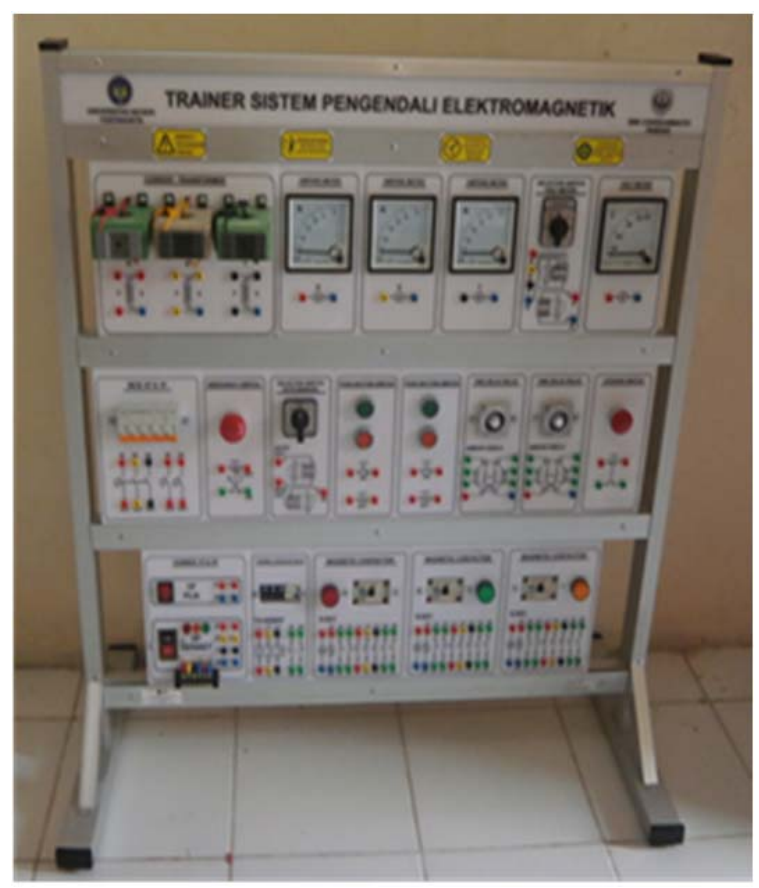

Figure 1. The electromagnetic control system training kit

To ensure the training kit to functionally work, a thorough functional-based test was conducted. The test was done by one experienced student of an undergraduate electrical engineering program. There were several items of tests that guarantee each module in the training kit was tested comprehensively. The results from this test can be used as an input for revising the electronic modules when there is a problem found. After that, the evaluation process continued by collecting the assessment from the experts. In this study, there are two groups of experts' judgment. The first one is the group of experts who evaluate the media design of the training kit, and the other one is the group of experts who assess the training kit concerning the learning material content.

Just after completing the initial product assessment and then considering some recommendations for product revision, the next work is implementing the training kit product to the user. In this case, the user was the group of XI grade students of the Electricity Utilization Installation Techniques Department of Cokroaminoto Pandak Vocational High School. The students have a chance to explore the capability of the product by practicing some control system tasks. At the end of the meeting, the students could give their opinion about the product by filling in the questionnaire distributed.

The last step of the development process of the training kit is evaluation. The evaluation should accommodate the entire process of instructional design. In this study, the evaluation was carried out by reviewing the findings of all evaluation results (functional-based test, experts' judgment, and userbased assessment).

\subsection{The Comprehensive Evaluation of Electromagnetic Control System Training Kit}

The comprehensive evaluation in this current study was conducted in three different approaches, i.e., functional-based test, experts' judgment, and userbased assessment. The first test, the functional-based test, is a type of test to verify each electronic module attached in the electromagnetic control system training kit whether it functionally works as designed. The functional-based test was administered by trying some scenarios of project work. The list of scenarios and including the test results is shown in Table 6. There were nine scenarios created that ensure each module in the training kit tested. Based on those test scenarios, it can be summarized that there was no critical problem found and all the modules could successfully work as designed.

Table 6. The functional-based test scenario

\begin{tabular}{|c|c|c|}
\hline No & Test Scenario & Test Result \\
\hline 1 & $\begin{array}{l}\text { 3-phase motor control from } \\
\text { one place }\end{array}$ & $\begin{array}{c}\text { The system responds as } \\
\text { designed }\end{array}$ \\
\hline 2 & $\begin{array}{l}\text { 3-phase motor control from } \\
\text { two different places }\end{array}$ & $\begin{array}{c}\text { The system responds as } \\
\text { designed }\end{array}$ \\
\hline 3 & $\begin{array}{c}\text { 3-phase motor control with } \\
\text { sequential order manual } \\
\text { mode }\end{array}$ & $\begin{array}{c}\text { The system responds as } \\
\text { designed }\end{array}$ \\
\hline 4 & $\begin{array}{c}\text { 3-phase motor control with } \\
\text { sequential order automatic } \\
\text { mode }\end{array}$ & $\begin{array}{c}\text { The system responds as } \\
\text { designed }\end{array}$ \\
\hline 5 & $\begin{array}{c}\text { 3-phase motor control - } \\
\text { right-left (forward-reverse) } \\
\text { manual mode }\end{array}$ & $\begin{array}{c}\text { The system responds as } \\
\text { designed }\end{array}$ \\
\hline 6 & $\begin{array}{l}\text { 3-phase motor control - } \\
\text { right-left (forward-reverse) } \\
\text { semi-automatic mode }\end{array}$ & $\begin{array}{c}\text { The system responds as } \\
\text { designed }\end{array}$ \\
\hline 7 & $\begin{array}{l}\text { 3-phase motor control Star- } \\
\text { Delta }(\mathrm{Y}-\Delta) \text { manual mode }\end{array}$ & $\begin{array}{c}\text { The system responds as } \\
\text { designed }\end{array}$ \\
\hline 8 & $\begin{array}{c}\text { 3-phase motor control Star- } \\
\text { Delta }(\mathrm{Y}-\Delta) \text { automatic } \\
\text { mode }\end{array}$ & $\begin{array}{c}\text { The system responds as } \\
\text { designed }\end{array}$ \\
\hline 9 & $\begin{array}{l}\text { Metering current and } \\
\text { voltage }\end{array}$ & $\begin{array}{c}\text { The system responds as } \\
\text { designed }\end{array}$ \\
\hline
\end{tabular}

The second evaluation in this study involves the judgment from experts. There are two points of evaluation in this concern: media design and learning material quality. The first point, the evaluation of the electromagnetic control system training kit, particularly in the aspect of media design, was carried out in order to know whether the training kit is feasible in terms of its physical appearance. The evaluation tried to look into three main aspects, namely, design, technical, and usefulness. The summary results, as can be seen in Table 7., show the total score collected from two experts. It can be noted that the total score for the first and second experts is 112 and 119, respectively. Furthermore, looking at the average of the total score, it has reached 115.5. Then, by taking into account the response criteria of 
Table 5., it can be summarized that two experts involved in the media aspect assessment judged the training kit as "very good". It means that the experts are satisfied with the product and justified it as feasible to use in the learning and teaching process in terms of the media design aspect.

Table 7. Assessment score from media experts

\begin{tabular}{|c|c|c|c|c|c|}
\hline \multirow{2}{*}{ No } & \multirow{2}{*}{ Evaluators } & \multicolumn{3}{|c|}{ Assessment Aspects } & Total \\
\cline { 3 - 5 } & & Design & Technical & Usefulness & Score \\
\hline 1 & Expert 1 & 37 & 49 & 26 & 112 \\
\hline 2 & Expert 2 & 38 & 54 & 27 & 119 \\
\hline & Average & 37.5 & 51.5 & 26.5 & 115.5 \\
\hline \multicolumn{2}{|c|}{ Criteria } & $\begin{array}{c}\text { Very } \\
\text { Good }\end{array}$ & $\begin{array}{c}\text { Very } \\
\text { Good }\end{array}$ & $\begin{array}{c}\text { Very } \\
\text { Good }\end{array}$ & $\begin{array}{c}\text { Very } \\
\text { Good }\end{array}$ \\
\hline
\end{tabular}

The second point of experts' judgment is focused on the evaluation of the aspect of the learning material. It is important to bear in mind that there are two aspects included in the assessment, i.e., learning material quality and usefulness. The results from two evaluators, as seen in Table 8., exhibit a positive assessment. The total scores from those evaluators are 78 and 82 , respectively. Therefore, the average from those scores is 80 . That average score is categorized in a "good" category based on the response criteria of Table 5. It means that the training kit of the electromagnetic control system is feasible to be used in the learning and teaching activities in terms of a learning material aspect.

Table 8. Assessment score from learning material experts

\begin{tabular}{|l|l|l|l|l|}
\hline \multirow{2}{*}{ No } & \multirow{2}{*}{ Evaluators } & \multicolumn{2}{|c|}{ Assessment Aspects } & \multirow{2}{*}{$\begin{array}{c}\text { Total } \\
\text { Score }\end{array}$} \\
\cline { 3 - 4 } & $\begin{array}{c}\text { Learning Material } \\
\text { Quality }\end{array}$ & Usefulness & \\
\hline 1 & Expert 1 & 50 & 28 & 78 \\
\hline 2 & Expert 2 & 53 & 29 & 82 \\
\hline & Average & 51,5 & 28,5 & 80 \\
\hline \multicolumn{2}{|c|}{ Criteria } & Good & Good & Good \\
\hline
\end{tabular}

Two previous evaluations have been conducted by experts, and this section will describe the result of evaluation that has been done by the user of the training kit. In this case, the evaluation is carried out by the students. There are four aspects of assessment; learning material quality, design of training kit, technical aspect, and usefulness. As stated before, there were 15 students involved in this assessment. From a total of 15 students' responses, the average score of each aspect, including its total, can be summarized as seen in Table 9. It shows that the total score of the students' response is 101.53. This score is categorized as "very good" based on the classification in Table 5. This means that the training kit of the electromagnetic control system is feasible to be utilized as the learning media in the learning process based on the students' perspective.
Table 9. Assessment score from the student's perspective

\begin{tabular}{|c|c|c|c|c|c|c|}
\hline \multirow[b]{2}{*}{ No } & \multirow[b]{2}{*}{ Evaluators } & \multicolumn{4}{|c|}{ Assessment Aspects } & \multirow[b]{2}{*}{$\begin{array}{l}\text { Total } \\
\text { Score }\end{array}$} \\
\hline & & \begin{tabular}{|c|} 
Learning \\
Material \\
Quality
\end{tabular} & $\begin{array}{l}\text { De- } \\
\text { sign }\end{array}$ & $\begin{array}{l}\text { Tech- } \\
\text { nical }\end{array}$ & $\begin{array}{c}\text { Useful } \\
\text { ness }\end{array}$ & \\
\hline 1 & Student 1 & 30 & 12 & 33 & 12 & 87 \\
\hline 2 & Student 2 & 40 & 14 & 38 & 16 & 108 \\
\hline 3 & Student 3 & 39 & 16 & 39 & 15 & 109 \\
\hline 4 & Student 4 & 35 & 14 & 36 & 15 & 100 \\
\hline 5 & Student 5 & 32 & 11 & 31 & 14 & 88 \\
\hline 6 & Student 6 & 40 & 16 & 38 & 15 & 109 \\
\hline 7 & Student 7 & 36 & 14 & 35 & 14 & 99 \\
\hline 8 & Student 8 & 39 & 16 & 39 & 16 & 110 \\
\hline 9 & Student 9 & 38 & 16 & 38 & 16 & 108 \\
\hline 10 & Student 10 & 39 & 16 & 37 & 14 & 106 \\
\hline 11 & Student 11 & 30 & 13 & 35 & 14 & 92 \\
\hline 12 & Student 12 & 39 & 16 & 36 & 13 & 104 \\
\hline 13 & Student 13 & 39 & 16 & 36 & 15 & 106 \\
\hline 14 & Student 14 & 35 & 13 & 31 & 15 & 94 \\
\hline 15 & Student 15 & 39 & 15 & 34 & 15 & 103 \\
\hline & Average & 36.67 & 14.53 & 35.73 & 14.6 & 101.53 \\
\hline & Criteria & $\begin{array}{l}\text { Very } \\
\text { Good }\end{array}$ & $\begin{array}{l}\text { Very } \\
\text { Good }\end{array}$ & $\begin{array}{l}\text { Very } \\
\text { Good }\end{array}$ & $\begin{array}{c}\text { Very } \\
\text { Good }\end{array}$ & $\begin{array}{c}\text { Very } \\
\text { Good }\end{array}$ \\
\hline
\end{tabular}

\section{Discussion}

The first aim of this study is to develop the learning media of the electromagnetic control system training kit that can be used in the learning activities, especially in the subject of installing and operating a control system. To address that particular objective, the widely used method for developing the instructional system, the ADDIE model, has been selected. This model comprises four sequential stages, i.e., analysis, design, development, implementation, and evaluation. Meanwhile, the learning media of the control system training kit was developed on the concept of modular-based. This modular concept may allow the big system to subdivide into several independent small parts to reduce complexity [14]. The independent in each part or module means that each module has a little or even no dependency on other modules. Consequently, when there is a change or an update in one module, it is not affecting other modules connected with it. In the context of troubleshooting, this situation may lead to the easiness of localizing the problem. It also reduces the cost in maintenance as consequent from the trouble found. This modularbased learning media is a suitable choice to implement in the learning process for engineering students. The engineering students require the ability to comprehend the system not only in general but also in detail. The students should also have the capability to find the solution from the problem found in the system. It can be done smoothly if the system has a modular construction. 
There is always a step of instructional design to ensure whether the instructional media developed is feasible to be used in the instructional activities. In this study, the comprehensive evaluation was conducted by implementing three different methods of evaluation. Those evaluations are the functionalbased test, experts' judgment, and user-based evaluation. Focused on the functional-based test, this test is one proper way to check whether the system is working functionally. This test takes into consideration only the output generated by the system in response to the specific input engaged [26]. This test has been successfully implemented in other study for evaluating an asynchronous serial communication learning media [6]. There were several scenarios of tests conducted to ensure each module in this study was tested. The results showed that each module developed has passed the test and functionally worked as designed. It is important to point out that the success of this test shows the feasibility of the training kit to be used in the learning process.

With regard to the experts' judgment, there are two points of assessment: media design and learning material. Concerning the media design, the results of experts' judgment revealed that the learning media developed was very good in design, technical, and usefulness aspects. Based on the response classification made in this study, it is clear to see that the "very good" grade is the highest level. Looking at the learning material aspect, the results of the assessment from experts showed that the quality and usefulness of learning material were in a "good" level, respectively. Although these results are not in a top grade, they are still acceptable. Therefore, it can be concluded that the learning media developed is feasible to be used for learning activities. The good feasibility of the learning media may implicate for achieving the learning goals effectively [27] and improving the learning outcomes [28].

Another evaluation has been done by involving the prospective user of the training kit. This kind of evaluation has been applied by many researchers in which some of them are [29] and [30]. The users in this study was a group of students of Cokroaminoto Pandak Vocational High School that followed the course of installing and operating a control system. The questionnaire on the basis of a 4-point Likert scale was used to collect the data. The results showed that all aspects of the assessment (learning material quality, product design, technical aspect, and usefulness) are categorized in a "very good" grade. This finding indicated the acceptance of the students on the learning media developed. This finding also showed that the product of media is feasible to be utilized in the learning process.

\section{Conclusion}

The development of the electromagnetic control system training kit in this study has been completely done through the ADDIE model. The training kit was designed based on the modular approach which was offering several advantages, i.e., reusability, ease of assembling and maintenance, and cost-saving. In order to ensure the training kit has been comprehensively evaluated, three different schemes of the evaluation were applied, i.e., functional-based test, experts' judgment, and user-based assessment. The findings showed that the training kit, including each module attached, has functionally worked as designed. Subsequently, the judgments from the media-based and learning material-based experts were categorized in "very good" and "good" criteria, respectively. It is also worth noting that according to the users' responses, the training kit could be categorized in a "very good" level. All in all, based on those three kinds of evaluation, it can be concluded that the electromagnetic control system training kit is feasible to use as a modular-based learning media in the learning activities. This conclusion may implicate the enhancement of student learning achievement, especially in the subject of installing and operating a control system.

Although the findings of this study look convincing and promising, there are still some drawbacks found that could be considered for future work. The one that should be important to take into account is the duration of students in using and practicing the training kit developed. It will be better if the duration of students' experiments in this study is longer instead of limited meeting hours. The longer time for the experiment may explore the weakness that has not been revealed before.

\section{Acknowledgements}

We would like to thank the Cokroaminoto Pandak Vocational High School, Bantul, Yogyakarta, for facilitating this research.

\section{References}

[1]. Zohrabi, M., Torabi, M. A., \& Baybourdiani, P. (2012). Teacher-centered and/or student-centered learning: English language in Iran. English language and literature studies, 2(3), 18.

[2]. Agrahari, R. (2016). The nature of educational reform and change: From teacher-centered to studentcentered learning. Educational Quest-An International Journal of Education and Applied Social Sciences, 7(2), 133-139.

[3]. Emaliana, I. (2017). Teacher-centered or studentcentered learning approach to promote learning?. Jurnal Sosial Humaniora (JSH), 10(2), 5970. 
[4]. Jones, L. (2007). The Student-Centered Classroom. Cambridge: Cambridge University.

[5]. Croft, R. S. (2004). Communication theory. Eastern Oregon University, La Grande, OR.

[6]. Hariyanto, D., Nugraha, A. C., \& Asmara, A. (2018). Design and Development of an Asynchronous Serial Communication Learning Media to Visualize the Bit Data. In Journal of Physics: Conference Series (p. 12010).

[7]. Hamalik, O. (1994). Media Pendidikan, cetakan ke7. Bandung: Penerbit PT. Citra Aditya Bakti.

[8]. Sanaky, H. A. (2013). Media pembelajaran interaktifinovatif. Yogyakarta: Kaukaba Dipantara.

[9]. Gerlach, V. S., \& Ely, D. P. (1971). Teaching and media: A systematic approach. Prentice Hall Englewood Cliffs, NJ.

[10]. Arsyad, A. (2013). Media pembelajaran edisi revisi. Jakarta: Rajawali Pers.

[11]. Arief, S. (2009). Media pendidikan, pengertian, pengembangan, dan pemanfaatannya. Jakarta: PT. Rajagrafindo Persada.

[12]. Yamin, M. (2007). Desain Pembelajaran Berbasis Tingkat Satuan Pendidikan. Jakarta.

[13]. Fedorov, A. V. (2007). Media Education: Sociological Surveys. Taganrog: Publishing House Kuchma, 228.

[14]. Björk, E. (2012). Universal Design or ModularBased Design Solutions-A Society Concern. Assistive Technologies, 121.

[15]. Chan, Y. F., Moallem, M., \& Wang, W. (2007). Design and implementation of modular FPGA-based PID controllers. IEEE transactions on Industrial Electronics, 54(4), 1898-1906.

[16]. Dick, W. \& Carey, L. (1990).The systematic design of instruction(3rd ed.). Glenview, IL: Scott, Foresman and Co.

[17]. Crocker, L., \& Algina, J. (1986). Introduction to classical and modern test theory. Holt, Rinehart and Winston, 6277 Sea Harbor Drive, Orlando, FL 32887.

[18]. Haynes, S. N., Richard, D., \& Kubany, E. S. (1995). Content validity in psychological assessment: A functional approach to concepts and methods. Psychological assessment, 7(3), 238.
[19]. Arikunto, S. (2006). Prosedur suatu pendekatan praktik. Jakarta: Rineka Cipta.

[20]. Landauer, T. K. (1997). Behavioral research methods in human-computer interaction. In Handbook of human-computer interaction (pp. 203-227). NorthHolland. https://doi.org/10.1016/b978-044481862-1/50075-3

[21]. Nunnally, J. C., \& Bernstein, I. H. (1978). Chapter 7: the assessment of reliability. Psychometric theory, 264-5.

[22]. Tredoux, C., \& Durrheim, K. (2002). Numbers, Hypotheses \& Conclusions: A Course in Statistics for the Social Sciences. Lansdowne: UCT Press.

[23]. Sudjana, N. (1995). Penilaian hasil proses belajar mengajar. PT Remaja Rosdakarya.

[24]. Widoyoko, E. P. (2009). Evaluasi program pembelajaran. Yogyakarta: pustaka pelajar, 238.

[25]. Lee, W. W., \& Owens, D. L. (2004). Multimediabased instructional design: computer-based training, web-based training, distance broadcast training, performance-based solutions. John Wiley \& Sons.

[26]. IEEE Standards Coordinating Committee. (1990). IEEE Standard Glossary of Software Engineering Terminology (IEEE Std 610.12-1990). Los Alamitos. CA: IEEE Computer Society, 169.

[27]. Peppler, K. A., \& Kafai, Y. B. (2007). From SuperGoo to Scratch: Exploring creative digital media production in informal learning. Learning, media and technology, 32(2), 149-166.

[28]. Danielsson, K., \& Wiberg, C. (2006). Participatory Design of Learning Media: Designing Educational Computer Games with and for Teenagers. Interactive Technology and Smart Education, 3(4), 275-291.

[29]. Faruk, A. (2014). Development of Interactive Learning Media Based Lectora Inspire in Discrete Method Course. Proceeding of International Conference On Research Implementation and Education of Mathematics and Sciences. ISBN: 9780979-99314-8-1.

[30]. Hariyanto, D., Triyono, M. B., \& Köhler, T. (2020). Usability evaluation of personalized adaptive elearning system using USE questionnaire. Knowledge Management \& E-Learning: An International Journal, 12(1), 85-105. 